\title{
Regionalizm w gospodarce globalnej. Próba analizy tendencji terytorializacji produkcji
}

\author{
ROZWÓJ GOSPODARKI POSTFORDIAŃSKIEJ, \\ WZROST ZNACZENIA MAŁYCH I ŚREDNICH FIRM
}

Pod koniec lat 70. pojawiły się w gospodarce światowej i w naukach ekonomicznych nowe tendencje rozwoju. Dostrzeżono możliwość "trzeciej drogi” w rozwoju gospodarczym: poza brakiem rozwoju i wzrostem wielkich, światowych korporacji. Tym trzecim wyjściem zdaje się być rozwój małych i średnich firm. Nie oznacza to naturalnie, że te firmy nie istniały poprzednio, nie doceniano natomiast ich znaczenia dla rozwoju gospodarczego kraju; traktowano je, zarówno w neoklasycznej teorii ekonomicznej, jak i w opinii polityków, planistów i decydentów, jako gatunek przestarzały, "skazany na wymarcie". Ogólna sytuacja gospodarcza końca lat 70., a zwłaszcza w latach 80. i 90., w szczególny sposób sprzyja rozwojowi małych i średnich przedsiębiorstw produkcyjnych i usługowych. Następuje spadek znaczenia nieskomplikowanych, podstawowych działań, wzrasta rola wykształcenia, w tym fachowego, zawodowego, które często wymaga długotrwałego przygotowania i praktycznej nauki.

Znaczny wzrost roli małych i średnich firm i ich udziału w obrotach handlowych wynika w dużej mierze z rozwoju systemu podwykonawców, stosowanego powszechnie także przez duże międzynarodowe koncerny, kiedy to podwykonawcy w rzeczywistości produkują większość wyrobów. Zwłaszcza przemysły zaawansowanych technologii mają tendencję do zlecania prac podwykonawcom, co jednocześnie obniża ich poziom ryzyka. W sytuacji wahań koniunktury i spadku popytu ograniczana jest liczba zleceń, przy zachowaniu stanu zatrudnienia w samym przedsiębiorstwie.

Zakłada się, że małe i średnie firmy lepiej dopasowują się do postmodernistycznej czy po-masowej gospodarki, która tworzy mało stabilny system i wymaga dużej elastyczności w specjalizacji. Małe i średnie firmy są przy tym lepiej zakorzenione w regionie, wymagają mniej biurokracji. Możliwy jest także rozwój bez wielkich nakładów finansowych. Generalnie mniejsze znaczenie odgrywa sam kapitał finansowy, wielką rolę przypisuje się natomiast "kapitałowi społecznemu", rozumianemu mniej jako "siła robocza”, bardziej jako zespół szeroko rozumianych powiązań międzyludzkich. Go- 
spodarka przekształca się w kierunku, o którym pisali M. Piore i C. Sabel (1984); powiązania i koncentrację wertykalną zastępują powiązania wertykalne.

Podstawowa w rozwoju firmy nie jest przy tym sama wielkość firmy, mierzona zatrudnieniem czy wielkością produkcji; ważny jest system powiązań, jaki jest wytwarzany między podmiotami produkcji. Końcowy produkt jest wytwarzany coraz częściej przez system współpracujących i współzależnych przedsiębiorstw; związki między nimi są znacznie bardziej elastyczne i wytrzymałe na przejawy niestabilności systemu gospodarczego niż powiązania między wydziałami tego samego przedsiębiorstwa. Zwykle także wielkie koncerny przemysłowe, będące własnością jednej grupy finansowej, składają się z szeregu autonomicznych podmiotów gospodarczych, co ma uelastycznić powiązania i ułatwić zarządzanie.

Współczesny system gospodarczy przekształca się dynamicznie. Gospodarka charakteryzuje się niepewnością, co wynika z globalnego systemu ekonomicznego i prowadzi do wyprowadzania wielu działalności i funkcji za zewnątrz, zlecając je podwykonawcom, co prowadzi do eksternalizacji. Wynikający z tego wzrost kooperacji i powiązań przynosi wzrost transakcji. Koncentracja przestrzenna natomiast wyraźnie zmniejsza koszty transakcji i ułatwia ich dokonywanie.

Dla niewielkich podmiotów gospodarczych szczególnie ważną rolę odgrywają czynniki lokalne, które często nie mają większego znaczenia dla dużych koncernów. Do czynników tych należą tradycja i kultura oraz powiązania interpersonalne. Przy ewidentnym wzroście liczby zawieranych transakcji terytorium odgrywa szczególną rolę nie tylko jako element minimalizacji kosztów, ale także jako koordynator powiązań. Uważa się, że kultura terytorialna w swym szerokim rozumieniu pełni rolę takiego właśnie zwornika powiązań społecznych i gospodarczych. Dodatkowo współwystępowanie

może ułatwiać dostęp do innowacji, szczególnie istotny dla przemysłów zaawansowanych technologii.

Podejmowane są przy tym liczne próby pomiaru tych trudnych do scjentyzacji behawioralnych powiązań, poprzez tworzenie licznych indeksów zaufania czy wskaźników atrakcyjności.

\section{PRODUKCJA INTERPERSONALNA I INTELEKTUALNA}

Przemiany społeczne i gospodarcze ostatnich 20 lat prowadzą do spadku znaczenia produkcji masowej i rynkowej. W podziale na systemy produkcji wg M. Storpera (1997) następuje natomiast wzrost produkcji interpersonalnej i intelektualnej.

Wraz z ograniczaniem produkcji masowej i rynkowej zauważalny jest także spadek znaczenia kodyfikowalnych produktów przemysłowych, czyli takich, w których zawarta jest całkowita wiedza o produkcji wyrobu; wystarczy tylko kupić produkt średniej klasy jakościowej i - przy użyciu odpowiedniego kapitału - można skopiować ten 
produkt. Produkty niekodyfikowalne natomiast są niekosmopolityczne, zwykle związane $\mathrm{z}$ wytwórcami, często $\mathrm{w}$ określonym regionie. Zawierają one trudną do odtworzenia wiedzę praktyczną; często $\mathrm{w}$ tych niemożliwych do kodyfikacji produktach zawarte są powiązania przestrzenne, społeczne, trudne do kopiowania. Naturalnie, można przykładowo skopiować kształt tosteru Alessi, ale nie osiagnie się podobnej ceny i jakości. Niekodyfikowalne produkty, do których należy ekskluzywna odzież projektantów mody czy inne artykuły konsumpcyjne są wytworami interpersonalnymi, które bazują na zaufaniu klienta do producenta i odgadywaniu przez producenta potrzeb i gustów klientów. Niezbędna do ich produkcji wiedza i praktyczne umiejętności są trudne do kopiowania

i uczenia się. Często kupując produkt, kupuje się jakąś część producenta, zwykle utożsamianą z jego nazwiskiem, często dodatkowo z regionem pochodzenia, gdy mówi się np. o włoskich butach czy szwajcarskich zegarkach. Rynek w tym przypadku wyraźnie opiera się na dwustronnym porozumieniu producenta i klienta oraz ich interpersonalnym związku.

W neoklasycystycznych szkołach ekonomicznych zakładano, że inwestycje (kapitał) są bardzo mobilne, problem zaś polega na przyciągnięciu tych inwestycji na określone obszary. Narodowość czy regionalizm nie miały tu znaczenia, rozwój gospodarczy utożsamiano wyłącznie z opanowywaniem rynków przez ponadnarodowe korporacje.

W postfordiańskiej gospodarce natomiast narodowość czy regionalizm, w zależności od rozumienia regionu, odgrywają zasadniczą rolę. L. Tyson (1990) uważa, że firmy nie są tak mobilne, jak uważali neoklasyczni ekonomiści, w tym R. Reich (1991). Ta sama autorka podaje, że tylko $25 \%$ dużych firm działa głównie poza krajem swojego pochodzenia i dotyczy to głównie dużych firm w małych krajach, jak Volvo, Nestle czy Philips. Często także te duże firmy są raczej organizatorami produkcji niż faktycznymi producentami wyrobów. Uważa się, że globalizacja produkcji w drugiej połowie lat 90. jest zbliżona do poziomu globalizacji rynków w 1914 roku. Szacuje się obecnie, że $89 \%$ gospodarki amerykańskiej jest narodowa czy regionalna. Także jedynie $20 \%$ dużych firm Nowego Jorku, który uchodzi za symbol globalizacji gospodarki, nie rozpoczęło działalności w stanie Nowy Jork.

Regionalizacja gospodarki współczesnej zdaje się przybierać dwie formy:

- deterytorializacji - występuje w sytuacji, gdy firma produkuje swoje wyroby lokalnie, sprzedaje je natomiast na całym świecie. Nie jest to powszechne zjawisko i dotyczy wysoce wyspecjalizowanych firm, często bardzo innowacyjnych i interpersonalnych;

- terytorializacji - obejmuje produkcję przeznaczoną na lokalny rynek. Dotyczy to większości artykułów konsumpcyjnych, szczególnie wyrobów przemysłu spożywczego. Często dodatkowo terytorializacja jest pogłębiana przez system ceł i innych opłat granicznych, wpływających na rozwój rynków lokalnych.

Terytorializacja i regionalizacja produkcji jest składową i wynikiem rewolucji jakościowej w postmodernistycznej gospodarce, która nastąpiła i następuje po rewolucji 
ilościowej. Przy produkcji nastawionej na ilość nie jest ważne, kto i gdzie produkuje określone dobra masowe; przy produkcji jakościowej szczególne znaczenie uzyskuje miejsce czy region produkcji, jako wyznacznik jakości i przejaw interpersonalnych powiązań nabywcy $\mathrm{z}$ producentem.

\section{POSTFORDIAŃSKIE REGIONY GOSPODARCZE}

Empiryczne przykłady wskazują szereg regionów, których rozwój gospodarczy, w tym głównie przemysłowy, często nowoczesnych technologii, oparty był na elastycznych, bazujących na nauce i uczeniu się systemach produkcji. Regiony takie tworzą setki niewielkich przedsiębiorstw, często o zbliżonym profilu produkcji. Do regionów tych można zaliczyć Emilię Romanię i Toskanię w środkowych Włoszech, Toyota City na Honsiu, Sillicon Valley, Orange County, Route 128 w USA, Cité Scientifique w Île-de-France, Badenię Wittenbergię i Bawarię. Poza tymi, w większości dobrze znanymi

regionami, można także wyróżnić mniej znane i o często niższym poziomie zaawansowania technologicznego, jak np. dzielnice finansowe Londynu i Nowego Jorku, dzielnica odzieżowa Los Angeles, przemysł meblowy północnej Karoliny i rozrywkowy Hollywood, przemysł metalurgiczny Haute Savoie we Francji i region Sakaki w Japonii, rzemieślniczy region Jutlandii, produkcja dywanów w Belgii, przemysł jubilerski Izraela, odzieżowy

w Galicji oraz wiele innych, mniej znanych regionów. Regiony gospodarcze nie zawsze, choć często, są tożsame z regionami historycznymi czy geograficznymi.

Region występowania dla wielu małych i średnich firm jest częścią, zwykle świadomej, strategii marketingowej. Dobra opinia o określonym produkcie z regionu odnosi się zwykle do wszystkich, niewielkich często, firm regionu. Przykładem może być produkcja czekolady w Belgii czy zegarków w Szwajcarii, gdzie nazwa regionu jest ewidentnym dobrem marketingowej, często finansowo mierzalnej wartości.

Staje się ewidentne, że wraz ze wzrostem handlu światowego i przepływu kapitału wzrasta ranga narodowych czy regionalnych specyfik w zakresie produkcji i technologii; w pewnym sensie integracja przyniosła nie tyle unifikację czy ujednolicenie, lecz specjalizację regionalną produkcji. Globalne mechanizmy gospodarcze dążą przy tym do powielania i rozpowszechniania odnoszących sukces modeli lokalnych; stąd też, przy udziale planistów i decydentów, powstają próby kopiowania regionów, czego najlepszym przykładem mogą być liczne Doliny, wzorowane na kalifornijskiej Silicon Valley, jednakże mimo często olbrzymich nakładów finansowych, żadna z kopii Doliny Krzemowej nie może być obecnie porównywalna pod względem wielkości, rangi i roli z pierwowzorem. Podejmowano także próby tworzenia drugej Japonii czy Ameryki, jednakże nie udaje się kopiować, podstawowych jak się wydaje, lokalnych powiazań społeczno-kulturowych, które warunkują rozwój regionów innowacyjnych. 


\section{KREOWANIE REGIONÓW I PLANOWANIE REGIONALNE}

Sterowanie rozwojem regionalnym i celowe, planowe kreowanie postfordystycznych regionów jest zadaniem zarówno trudnym, jak i ryzykownym. Regiony, w których często podstawą sukcesu jest wspominana wcześniej tradycja, są o tyle trudne do wykreowania, o ile skomplikowane czy wręcz niemożliwe jest odtworzenie czy zaplanowanie lokalnych powiązań społeczno-kulturowych. Przykładem podejmowanych prób w tym zakresie są inicjowane przez władze centralne parki technologiczne, zwane technopolami. Centra technologii czy biznes parki są formą tworzenia regionów czy mikroregionów produkcji dóbr wysokiej jakości (i ceny). Kompleksy zakorzenionych w lokalnych warunkach biznes parków mogą prowadzić do powstania regionów, jak np. Massachussets czy Korytarz M4 na wschód od Londynu.

Przykładem planowych przekształceń gospodarczych na dużą skalę jest planistyczna gospodarka Francji, gdzie w latach 40. i 50. przy wykorzystaniu różnorodnych narzędzi gospodarczych doprowadzono do zaniku wielu, często rękodzielniczych firm, a następnie, przy olbrzymich nakładach finansowych, podjęto próby kreowania tzw. technopolii, takich choćby jak Valbonne-Sophia Antipolis, Montpellier, Meylan w Grenoble.

\section{TERYTORIALIZACJA PRODUKCJI W POLSCE}

Rozwój terytorializacji produkcji przemysłowej w Polsce jest bardzo ograniczony przez lata gospodarki planowej i $\mathrm{w}$ niewielkim stopniu rozwinięty sektor małych $\mathrm{i}$ średnich firm. Brak jest więc wyraźnych regionów w postmasowym rozumieniu gospodarki. Regionem takim może stać się Wielkopolska, z koncentracją produkcji mebli o wysokim standardzie, lub Śląsk, gdy rozwiną się tam na przykład ponownie wytwórnie porcelany i fajansu wysokiej klasy (obecnie jest tam już renomowana fabryka fajansu stołowego

w Bolesławcu, sprzedająca swe wyroby za granicą pod marką Bunzlau i słynna fabryka porcelany Gische). Regionem takim mogą stać się okolice Łodzi, z rozwiniętym przemysłem odzieżowym, obecnie już głównie w sektorze małych i średnich firm.

Należy jednakże pamiętać, że w pełni wykształcone regiony tworzą się przez dziesięciolecia; jest to zarazem trudny do przewidzenia w efektach proces, który może przybierać różnorodne formy. Wydaje się, że obecnie w Polsce tworzą się zaczątki być może przyszłych postfordiańskich regionów produkcyjnych; rezultat tych procesów będzie zależał zarówno od aktywności gospodarczej i społecznej społeczności lokalnych, jak

i od decyzji politycznych, w tym administracyjnych, dotyczących podziału kraju oraz ogólnego rozwoju gospodarczego Polski, Europy i świata. 


\section{Literatura}

Benko G., 1993, Geografia technopolii, PWN, Warszawa

Lafontain O., Müller Ch., 1998, Keine Angst vor der Globalisierung, Dietz

Piore M., Sabel C., 1984, The Second Industrial Divide, Basic Books, New York

Reich R., 1991, The Work of the Nations: Preparing Ourselves for the 21st Century Capitalism, Alfred Knopf, New York

Storper M., 1997, The Regional World: Territorial Development in a Global Economy, Gulliford Press, New York

Tyson L., 1990, Who is Bashing Whom? Trade Conflicts in High Technology Industries, Institute for International Economics, Washington 